九州大学学術情報リポジトリ

Kyushu University Institutional Repository

Synthesis and properties of fullerene $\left(C_{-}\langle 70\rangle\right)$ complexes of 2,6-bis(porphyrin)-substituted pyrazine derivatives bound to a $\mathrm{Pd}(\mathrm{II})$ ion

Eda, Yusaku

Department of Chemistry, Faculty of Sciences, Kyushu University

Itoh, Kennosuke

Department of Chemistry, Faculty of Sciences, Kyushu University

Ito, Yoshio

Department of Chemistry, Faculty of Sciences, Kyushu University

Fujitsuka, Mamoru

The Institute of Scientific and Industrial Research (SANKEN), Osaka University

他

http://hdl. handle. net/2324/26038

出版情報：Supramolecular Chemistry. 22 (9)，pp.517-523，2010-09. Taylor \& Francis バージョン：

権利関係 : (C) 2010 Taylor \& Francis 


\title{
Synthesis and properties of fullerene $\left(C_{70}\right)$ complexes of 2,6- bis(porphyrin)-substituted pyrazine derivatives bound to a Pd(II) ion
}

\author{
Yusaku Eda, ${ }^{a}$ Kennosuke Itoh, ${ }^{a}$ Yoshio N. Ito, ${ }^{a}$ Mamoru Fujitsuka, ${ }^{b}$ \\ Tetsuro Majima, ${ }^{\mathrm{b}}$ and Toshio Kawato ${ }^{\mathrm{a} *}$ \\ ${ }^{a}$ Department of Chemistry, Faculty of Sciences, Kyushu University, 6-10-1 Hakozaki, \\ Higashi-ku, Fukuoka 812-8581, Japan \\ ${ }^{b}$ The Institute of Scientific and Industrial Research (SANKEN), Osaka University, 8-1 \\ Mihogaoka, Ibaraki, Osaka 567-0047, Japan
}

*Corresponding auther. E-mail: kawato@chem.kyushu-univ.jp

\begin{abstract}
2,6-Bis(porphyrin)-substituted 3,5-dimethylpyrazine and its zinc complex bound $\mathrm{C}_{70}$ to yield 1:1 inclusion complexes, which were characterised by ESI-MS, UV-Vis, fluorescence, and NMR spectroscopies. Association constants of the $\mathrm{C}_{70}$ complexes were determined by fluorescence and NMR spectral analyses. A decrease in absorbance of the Soret band of the pyrazine derivative by the effect of $\mathrm{C}_{70}$ was observed, suggesting the existence of a charge transfer interaction between $\mathrm{C}_{70}$ and porphyrin. Experimentally reliable values for the association constants were obtained by the NMR method and were about 6 times larger than those of the corresponding $\mathrm{C}_{60}$ complexes. Palladium complexation of the porphyrin-pyrazine ligand was found to enhance the association with fullerene. The association constant of 2,6-bis(porphyrin-Zn)-substituted 3,5dimethylpyrazine-Pd(II) complex with $\mathrm{C}_{70}$ was determined up to be $8400 \pm 900 \mathrm{M}^{-1}$. From the comparison of the association constants, it was found that inclusion room for $\mathrm{C}_{70}$ in the $\mathrm{Pd}(\mathrm{II})$ complex was maintained, juxtaposed between porphyrins attached to the opposite sides of the pyrazine ligands.
\end{abstract}

Keywords: fullerene; porphyrin; pyrazine; palladium(II) complex; association constant

\section{Introduction}

Once the significant properties of fullerene as an electron acceptor were recognised, ${ }^{1}$ many research attempts focused on the design and construction of host systems 
capable of capturing fullerene as a guest. ${ }^{2-7}$ In a previous paper we reported the synthesis of 2,6-bis(porphyrin)-substituted pyrazine which bound $\mathrm{C}_{60}$ to form a 1:1 inclusion complex. ${ }^{8}$ Now we attempt to construct a supramolecular system by the aid of $\mathrm{Pd}(\mathrm{II})$ complexation with the pyrazine ligands. In order to develop a better understanding of such a fullerene-inclusion system, we have extended our investigation by using $\mathrm{C}_{70}$ to show that the pyrazine ligand can embrace a proper fullerene between the porphyrins to form a stable inclusion complex. In this article, we will discuss structure and binding constants of a series of bis(porphyrin)-pyrazine derivatives with fullerenes.

\section{Results and discussion}

2,6-Bis(porphyrin)-substituted 3,5-dimethylpyrazine (1) and its $\mathrm{Zn}(\mathrm{II})$ complex (2) were prepared according to the previously reported procedure. ${ }^{8}$ Inclusion of $\mathrm{C}_{70}$ in the pyrazine ligand was confirmed first by means of mass spectrometry. The ESI-MS spectrum of a mixture of $\mathbf{1}$ and $\mathrm{C}_{70}$ exhibited a characteristic molecular ionic peak at 2022.4625 $\left(\left[\mathbf{1}+\mathrm{C}_{70}+\mathrm{H}\right]^{+}\right)$, which provided evidence for the formation of a 1:1 complex of $\mathbf{1}$ and $\mathrm{C}_{70}$ (Figure 1). For the sake of comparing $\mathrm{C}_{70}$ with $\mathrm{C}_{60}$ as a guest for $\mathbf{1}$ and $\mathbf{2}$, binding of $\mathrm{C}_{70}$ to $\mathbf{1}$ and $\mathbf{2}$ was then studied by the same methods as in the literature for $\mathrm{C}_{60} .{ }^{4,8}$ The fluorescence spectrum of $\mathbf{1}$ in toluene $(3.27 \mu \mathrm{M})$ exhibited a maximum at $650 \mathrm{~nm}$ upon excitation at $550 \mathrm{~nm}$. The fluorescence due to porphyrin 
upon excitation at the Q-absorption band was diminished by the addition of $\mathrm{C}_{70}$ in toluene (Figure S1). The Stern-Volmer plot for the fluorescence titration of $\mathbf{1}$ with $\mathrm{C}_{70}$ was found to be a straight line by plotting $F_{0} / F$ vs. $\left[\mathrm{C}_{70}\right]$, where $F_{0}$ and $F$ are the fluorescence intensities at $650 \mathrm{~nm}$ of $\mathbf{1}$ without and with $\mathrm{C}_{70}$, respectively (Figure S2). From the line-fitting analysis, the association constant $K_{\mathrm{a}}$ was calculated to be 17550 $\pm 170 \mathrm{M}^{-1}$. Analogous fluorescence quenching was observed for 2 with $\mathrm{C}_{70}$ in toluene (Figure S3). However, the Stern-Volmer plot at $596 \mathrm{~nm}$ for the fluorescence titration of $\mathbf{2}$ with $\mathrm{C}_{70}$ was found to curve upward. Therefore, the association constant $K_{\mathrm{a}}$ for $\mathbf{2}$ and $\mathrm{C}_{70}$ was determined by the Benesi-Hildebrand equation at $596 \mathrm{~nm}$ to be $16400 \pm$ $600 \mathrm{M}^{-1}$. The binding isotherm provides a good fit to 1:1 stoichiometry (Figure S4). These values for $\mathrm{C}_{70}$ are about 10 times larger than those of the corresponding $\mathrm{C}_{60}$ complexes. ${ }^{8}$ From these experiments, the association constants of $\mathrm{C}_{70}$ with $\mathbf{1}$ and $\mathbf{2}$ were determined to be larger than those of $\mathrm{C}_{60}$. This result shows that $\mathrm{C}_{70}$ fits well into the porphyrin-porphyrin pocket of $\mathbf{1}$ compared to $\mathrm{C}_{60}$. Such a tendency is consistent with similar metalloporphyrins reported in the literature. ${ }^{2,5,6}$

The UV-Vis spectrum of $\mathbf{1}$ in dichloromethane was influenced by the addition of $\mathrm{C}_{70}$ (Figure 2). The decrease of absorbance of the Soret band of $\mathbf{1}$ by the effect of $C_{70}$ suggests the existence of a charge transfer interaction between $C_{70}$ and $\mathbf{1}$. Since the spectral change was too small to carry out a titration experiment to measure 
accurate binding data, the association constant of $\mathbf{1}$ and $\mathrm{C}_{70}$ was estimated to be 3530 $\mathrm{M}^{-1}$ from the difference of two absorbance measurements $(0.0783$ at $415 \mathrm{~nm})$ taken of a solution of $1(2.03 \mu \mathrm{M})$ before and after addition of $\mathrm{C}_{70}(27.4 \mu \mathrm{M})$.
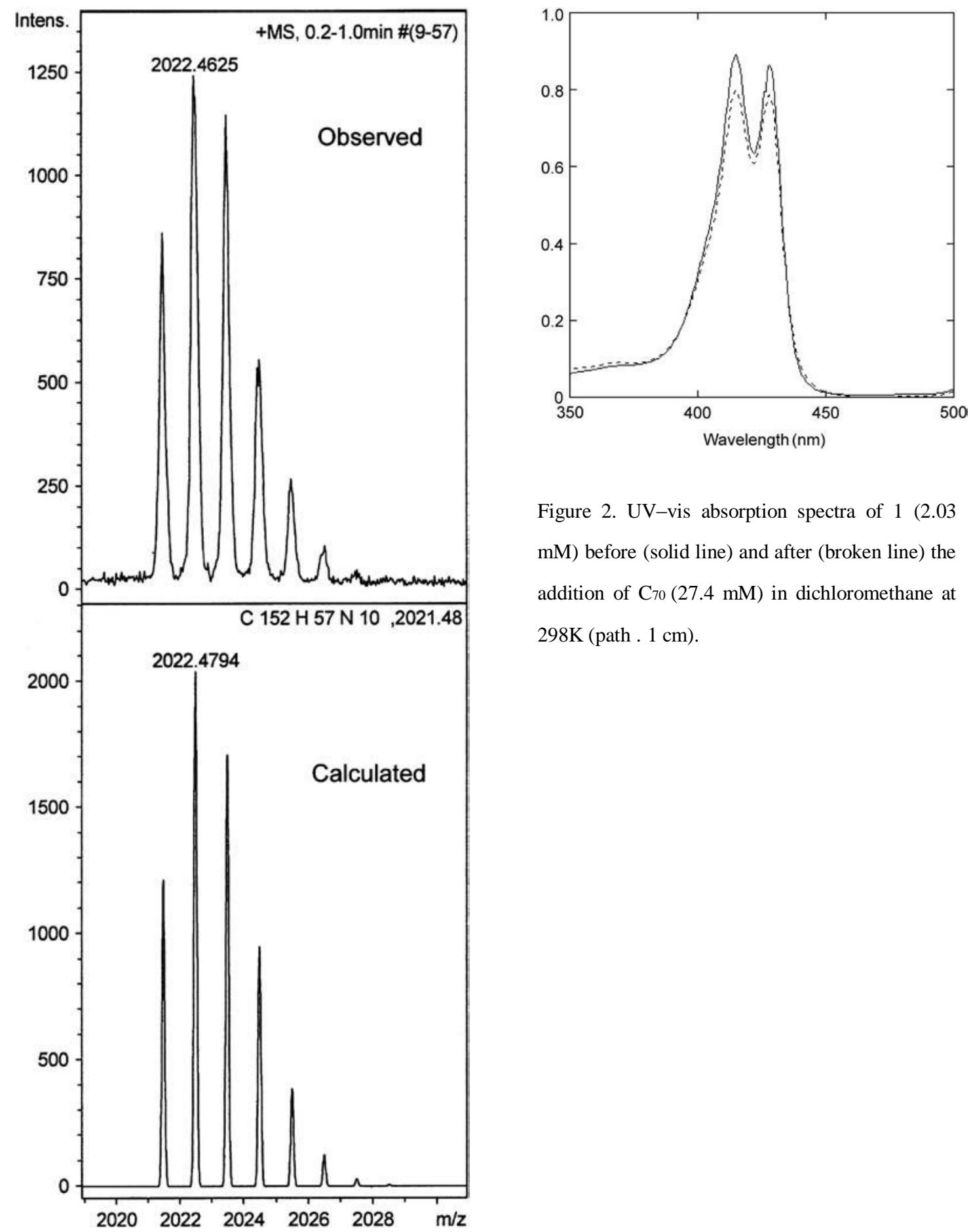

Figure 2. UV-vis absorption spectra of 1 (2.03 $\mathrm{mM}$ ) before (solid line) and after (broken line) the addition of $\mathrm{C}_{70}(27.4 \mathrm{mM})$ in dichloromethane at 298K (path . $1 \mathrm{~cm})$.

Figure 1. ESI-MS spectrum of a mixture of 1 and $\mathrm{C}_{70}$. 
Association of $\mathbf{1}$ and $\mathrm{C}_{70}$ in solution was then investigated by a ${ }^{1} \mathrm{H}$ NMR titration method $\left(270 \mathrm{MHz}, 296 \mathrm{~K}\right.$, toluene- $\left.d_{8}\right)$. With increasing concentrations of $\mathrm{C}_{70}$ in a mixture of $\mathbf{1}$ and $\mathrm{C}_{70}$ in toluene- $d_{8}$, the $\beta$-pyrrole proton $a$ near the pyrazine ring (Scheme 1) and NH proton of $\mathbf{1}$ shifted considerably upfield and the other $\beta$-pyrrole protons $b, c$ shifted slightly upfield, while the protons of the methyl groups attached to the pyrazine ring shifted downfield (Figure 3). These experimental results were similar to the case of $\mathrm{C}_{60}{ }^{5-7}$ Thus, the complexation of $\mathrm{C}_{70}$ was considered to take place in the expected porphyrin-porphyrin pocket of $\mathbf{1}$ (Scheme 1). These shifts are larger than those caused by addition of $\mathrm{C}_{60}$. NMR measurements of the methyl protons were suitable for the determination of the association constant $K_{\mathrm{a}}$. The association constant $K_{\mathrm{a}}$ was determined to be $4800 \pm 1300 \mathrm{M}^{-1}$ by nonlinear curve fitting of the NMR data with $K_{\mathrm{a}}$ and $\delta_{\max }$ treated as parameters (Figure 4). Complexation of 2 with $\mathrm{C}_{70}$ also takes place in solution as evidenced by changes in the chemical shifts of the protons of 2 by addition of $C_{70}$ (Figure 5). NMR measurements of the $\beta$-pyrrole proton $a$ were suitable for the determination of association constant $K_{\mathrm{a}}$. By a similar NMR titration method for $\mathbf{1}$, the association constant $K_{\mathrm{a}}$ of 2 with $\mathrm{C}_{70}$ was determined to be $3400 \pm 800 \mathrm{M}^{-1}$ (Figure 6). The amount of the toluene solution of guest fullerene was more than that of the initial host solution; however, we could not improve the NMR experimental conditions because 
of the low solubility of fullerene and its complex. Thus, the ${ }^{1} \mathrm{H}$ NMR titration method gave much smaller values for the association constant $K_{\mathrm{a}}$ than the fluorescence spectral method for $\mathbf{1}$ and $\mathbf{2}$. In our previous paper, ${ }^{8}$ we reported that association constants obtained by fluorescence and the NMR titration method did not agree within estimated standard deviations. In this study, the value estimated by UV absorption spectra seemed to support the value measured by the NMR method. The error in the fluorescence method might originate in inaccurately detected fluorescence intensities which are attributed to the scattering of the incident beam by coexisting fullerene molecules in solution.



Scheme 1. Possible structure of adducts of 2,6-bis(porphyrin)-substituted pyrazine derivatives (1-4) with fullerene. 
The association constant of $\mathrm{C}_{70}$ with $\mathrm{Zn}$ porphyrin complex 2 was smaller than that for $\mathbf{1}$ with metal-free porphyrins. This result is consistent with the result of calyx[4]arene-linked bis(porphyrin) hosts reported in the literature. ${ }^{6}$ Electron-rich porphyrin nitrogen atoms are effective for bond-stabilization by the dispersive forces associated with $\pi-\pi$ interactions between porphyrin and $\mathrm{C}_{70}$.

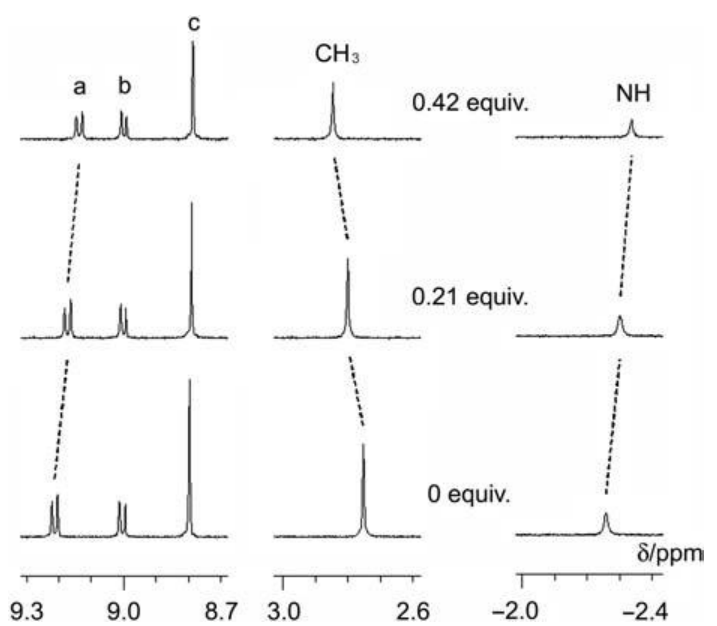

Figure 3. Partial $1 \mathrm{H}$ NMR spectra (270 MHz, $296 \mathrm{~K}$, toluened8) of 1 with $\mathrm{C}_{70}$. Assignments of peaks are shown in Scheme 1.

Next, the metal complexation effect on the association of the pyrazine derivatives with fullerene was investigated. Complexation of 1 with $\operatorname{Pd}(\mathrm{II})$ ion was achieved by refluxing a solution of $\mathbf{1}$ and $1 / 2$ molar amount of $\left[\mathrm{PdCl}_{2}\left(\mathrm{CH}_{3} \mathrm{CN}\right)_{2}\right]$ to afford 3 (Scheme 1). Comparison of the ${ }^{1} \mathrm{H}$ NMR peaks of $\mathbf{3}$ with those of $\mathbf{1}$ revealed a remarkable downfield shift $(\Delta \delta=1.13 \mathrm{ppm})$ for the methyl peak upon complexation. Therefore, two pyrazine ligands coordinated to a $\mathrm{Pd}(\mathrm{II})$ ion at the nitrogen whose neighbouring carbons were connected to less hindered methyl groups. From the analogy of $\mathrm{Pd}(\mathrm{II})$ complexes with 2,6-disubstituted $\mathrm{N}$-heterocyclic ligands, ${ }^{8,9}$ cis- 
coordination is impossible due to the steric repulsion between the substituents. Therefore, by the support of a Pd(II) ion to link two trans-pyrazine ligands, the juxtaposed porphyrin groups on the opposite side of the ligands can approach each other. Such an arrangement of the binding sites is essential for the system to work well as a host molecule. ${ }^{9}$



Figure 4. Changes in the chemical shift of the proton of the methyl group in 1 by the addition of $\mathrm{C}_{70}$ in toluene-d8 at $296 \mathrm{~K}$. The solid line is the theoretical isotherm obtained by nonlinearcurve fitting to the experimental data.

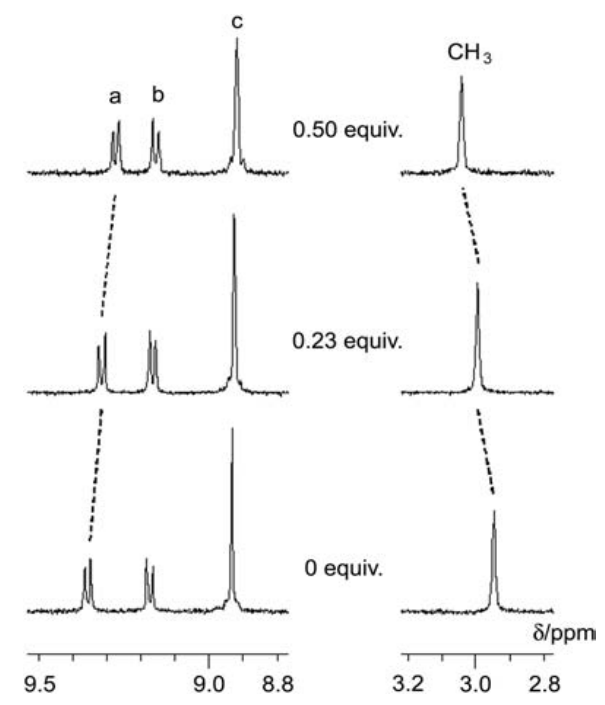

Figure 5. Partial 1H NMR spectra (270 MHz, 296 K, toluened8) of 2 with C70. Assignments of peaks are shown in Scheme 1 . 




Figure 6. Changes in the chemical shift of b-pyrrole proton a in 2 by addition of $\mathrm{C}_{70}$ in toluene-d8 at $296 \mathrm{~K}$. The solid line is the theoretical isotherm obtained by nonlinear curve fitting to the experimental data. $520 \mathrm{Y}$. Eda et al.

The ground state absorption spectrum of $\mathbf{3}$ displayed one broad Soret absorption peak at $418 \mathrm{~nm}$ (Figure 7). The figure is explained by the overlapping of peaks due to further splitting of the original Soret absorption bands by exciton couplings that originated from Coulombic interactions between transition dipole moments of the four porphyrins in $\mathbf{3}$. The fluorescence spectrum of $\mathbf{3}$ exhibited a peak at $648 \mathrm{~nm}$ upon excitation by $553 \mathrm{~nm}$ light in dichloromethane $(2.0 \mu \mathrm{M})$. Since the emission from $\mathbf{3}$ is similar to that from free ligand $\mathbf{1}$ (emission peak maximum: 650 $\mathrm{nm})$, the singlet excited state of $\mathbf{1}$ is not influenced by complexation with a $\operatorname{Pd}(\mathrm{II})$ ion.

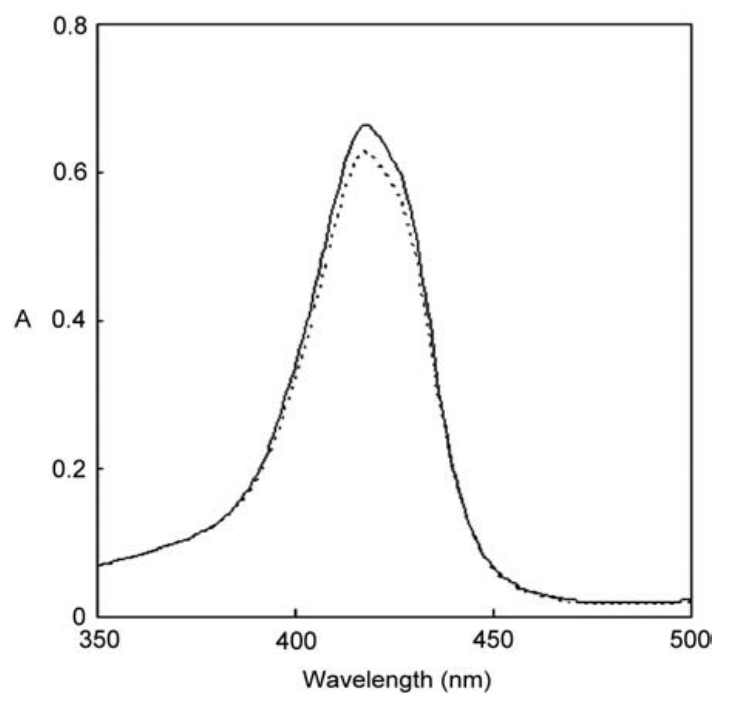


Figure 7. UV-vis absorption spectra of $3(2.0 \mathrm{mM})$ before (solid line) and after (broken line) addition of $\mathrm{C}_{70}$ $(27.5 \mathrm{mM})$ in dichloromethane at $298 \mathrm{~K}$ (path $.1 \mathrm{~cm})$.
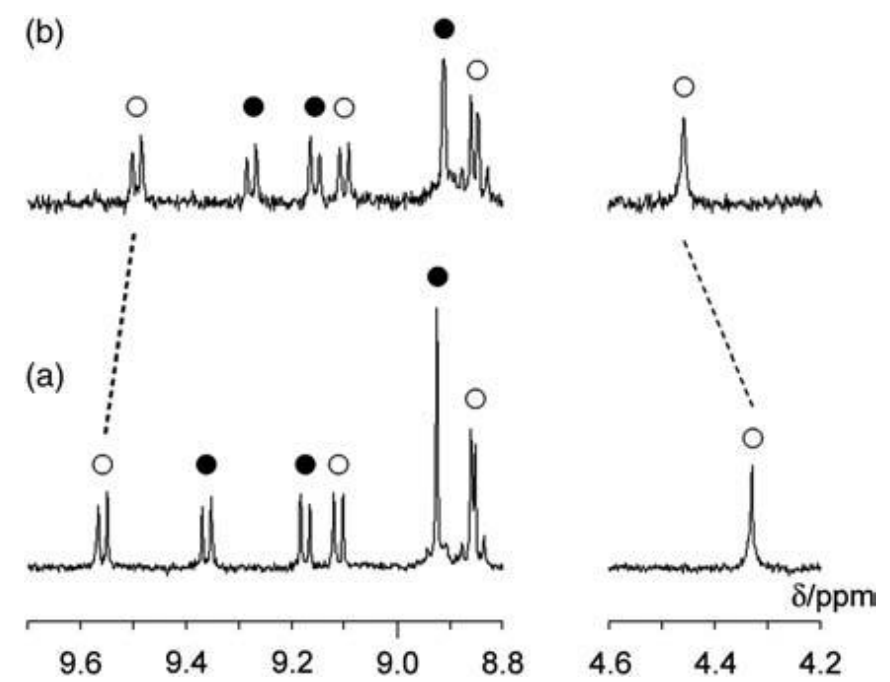

Figure 8. $1 \mathrm{H}$ NMR spectra of 1:2 mixture of $4(\mathrm{~W})$ and $2(\mathrm{X})$ before (a) and after (b) addition of an overall stoichiometric deficit of $\mathrm{C}_{70}$ in ratio 1:2:2.1.

The UV-Vis spectrum of $\mathbf{3}$ in dichloromethane was altered by the addition of $\mathrm{C}_{70}$ (Figure 7). The decrease of absorbance of the Soret band of $\mathbf{3}$ by the effect of $\mathrm{C}_{70}$ suggests the existence of a charge transfer interaction between $\mathrm{C}_{70}$ and $\mathbf{3}$. However, the degree of spectral change was not enough to measure an accurate binding constant for the complex. Furthermore, we could not carry out a ${ }^{1} \mathrm{H}$ NMR titration to measure the binding constant of $\mathbf{3}$ and $\mathrm{C}_{70}$ because of the low solubility of $\mathbf{3}$ in toluene. Thus, we could not determine the structure of the inclusion compound of $\mathbf{3}$ with $\mathrm{C}_{70}$. Complexation of 2 with a $\mathrm{Pd}(\mathrm{II})$ ion was then achieved similarly by refluxing a solution of 2 and 1/2 molar amount of $\left[\mathrm{PdCl}_{2}\left(\mathrm{CH}_{3} \mathrm{CN}\right)_{2}\right]$ to afford 4 (Scheme 1). Since analytically pure $\mathrm{Pd}(\mathrm{II})$ complex was not obtained, the association of $\mathbf{4}$ and fullerene 
was investigated as a mixture of 2 and $\mathbf{4}$ by a ${ }^{1} \mathrm{H}$ NMR titration method (270 MHz, $296 \mathrm{~K}$, toluene- $\left.d_{8}\right)$. With increasing concentrations of $\mathrm{C}_{70}$ in a mixture of 4 and $\mathrm{C}_{70}$ in toluene- $d_{8}$, the $\beta$-pyrrole proton $a$ shifted considerably upfield and the other $\beta$-pyrrole protons shifted slightly upfield, while the protons of the methyl groups attached to the pyrazine ring shifted downfield (Figure 8). As probable structures of the complex of $\mathbf{4}$ and $\mathrm{C}_{70}$, desired form $\mathbf{B}$ as well as form $\mathbf{A}$ were considered (Scheme 1). NMR data measurements of the $\beta$-pyrrole proton $a$ were suitable for the determination of association constant $K$, which was found to be $7.1( \pm 1.5) \times 10^{7} \mathrm{M}^{-2}$. The association constant $K_{1}$ was then calculated to be $8400 \pm 900 \mathrm{M}^{-1}$ since the value of $K_{2}$ would be equal to that of $K_{1}\left(K=K_{1} K_{2}=K_{1}^{2}\right)$ due to the independence of the two sites of the host. This is attributed to no structural change of $\mathbf{4}$ after first binding with fullerene because the N-Pd-N bond is not likely to be flexible due to the steric hindrance of the methyl groups attached to the pyrazine rings. Possible forms of adducts of $\mathbf{4}$ and fullerene are shown in Scheme 1. In the case of form $\mathbf{A}$ in which inclusion room for $\mathrm{C}_{70}$ in the $\mathrm{Pd}(\mathrm{II})$ complex was maintained in the same position as that in 2 , the $K_{1}$ value should be close to the $K_{\mathrm{a}}$ of 2 . The fact that the value of $K_{1}$ is much larger than $K_{\mathrm{a}}$ of $\mathbf{2}$ suggests form $\mathbf{B}$ as the plausible structure of the adduct. ${ }^{10}$ Association of $\mathbf{4}$ and $\mathrm{C}_{60}$ in toluene- $d_{8}$ solution was similarly investigated. The association constant $K$ was determined to be $4.3( \pm 0.8) \times 10^{6} \mathrm{M}^{-2}$ and the association constant $K_{1}$ was estimated 
to be $2100 \pm 200 \mathrm{M}^{-1}$, which was $1 / 4$ of that for $\mathrm{C}_{70}$. Experimentally reliable association constants of bis(porphyrin)pyrazine derivatives and fullerene are summarised in Table 1. The effective enhancement of the binding with fullerene by $\operatorname{Pd}(\mathrm{II})$ complexation of the host is attributable to the proper bite angle ( $60^{\circ}$ for $4 \mathrm{vs}$. $120^{\circ}$ for $\mathbf{1}$ and 2 ) formed by the two porphyrin rings to capture fullerene between them.

\begin{tabular}{ccc}
\hline & $\mathrm{C}_{60}$ & $\mathrm{C}_{70}$ \\
\hline $\mathbf{1}$ & $830 \pm 50^{8}$ & $4800 \pm 1300$ \\
$\mathbf{2}$ & $550 \pm 180^{8}$ & $3400 \pm 800$ \\
$\mathbf{4}$ & $2100 \pm 200$ & $8400 \pm 900$ \\
\hline
\end{tabular}

Table 1. Association constants of 1 and $2\left(\mathrm{~K}_{\mathrm{a}} / \mathrm{M}_{21}\right)$ and $4\left(\mathrm{~K}_{1} / \mathrm{M}_{21}\right)$ with fullerene obtained by the $1 \mathrm{H}$ NMR titration method (270 MHz, $296 \mathrm{~K}$, toluene-d8).

In conclusion, a pyrazine derivative with porphyrin rings at the 2,6-positions was a significantly better host for $\mathrm{C}_{70}$ than for $\mathrm{C}_{60}$. The association constant of each adduct was determined successfully by an NMR titration method. It was found that palladium complexation of the porphyrin-pyrazine ligand enhanced the association of the host with fullerene. Since photo-excited energy transfer is an important process in the early stages of photosynthesis, ${ }^{11}$ we are now attempting to construct a new system in which photo-excited energy transfer arises from a proper metal ion to $\mathrm{C}_{70}$ through the bridging pyrazine moiety connecting the energy donor and acceptor. 


\section{Experimental Section}

\section{General comments}

UV-Vis spectra were measured by a Shimadzu UV-2200 spectrophotometer.

Fluorescence spectra were measured by a Hitachi F-2500 spectrophotometer. ${ }^{1} \mathrm{H}$ NMR spectra were recorded on a JEOL GSX-270 FT NMR spectrometer with $\mathrm{CDCl}_{3}$ or $\mathrm{C}_{6} \mathrm{D}_{5} \mathrm{CD}_{3}$ as solvent and TMS as internal standard $(\delta=0 \mathrm{ppm})$. ESI-MS spectra were determined on a Bruker Daltonics MicroTOF-ks1focus ESI-TOF-MS spectrometer. Silica gel 60 (MERCK) was used for column chromatography. 2,6Bis(10,15,20-triphenylporphyrin-5-yl)-3,5-dimethylpyrazine (1) and its Zn complex (2) were prepared according to the literature. ${ }^{8}$

\section{Materials}

trans-Dichlorobis[2,6-bis(10,15,20-triphenylporphyrin-5-yl)-3,5-dimethylpyrazine]

palladium(II) (3)

A solution of trans $-\mathrm{PdCl}_{2}\left(\mathrm{CH}_{3} \mathrm{CN}\right)_{2}$ in benzene $(1.7 \mathrm{mM}, 0.933 \mathrm{~mL})$ was added dropwise to a solution of $\mathbf{1}(3.8 \mathrm{mg}, 3.2 \mu \mathrm{mol})$ in benzene $(3 \mathrm{~mL})$. After refluxing for $4 \mathrm{~h}$, the solution was concentrated in vасио and the residue was purified by column chromatography on silica gel, eluting with $\mathrm{CH}_{2} \mathrm{Cl}_{2}$ to afford $3(2.6 \mathrm{mg}, 63 \%)$ as a purple solid. ${ }^{1} \mathrm{H}$ NMR $\left(270 \mathrm{MHz}, \mathrm{CDCl}_{3}\right): \delta-2.79$ (br s, 8H, NH), 3.77 (s, 12H, Pz$\mathrm{CH}_{3}$ ), 7.65-7.80 (m, 36H, PhH), 7.97-8.29 (m, 24H, PhH), 8.77 (s, 16H, $\beta$-pyrrole), 
8.97-9.13 ppm (m, 16H, $\beta$-pyrrole); UV-Vis $\left(\mathrm{CH}_{2} \mathrm{Cl}_{2}\right): \lambda_{\max } 418(\varepsilon=330000), 521$ (36000), 553 (14000), 591 (9300), $646 \mathrm{~nm}\left(6300 \mathrm{dm}^{3} \mathrm{~mol}^{-1} \mathrm{~cm}^{-1}\right)$; Fluorescence $\left(\mathrm{CH}_{2} \mathrm{Cl}_{2}, \lambda_{\text {ex }} 553 \mathrm{~nm}\right): \lambda_{\text {em }} 648 \mathrm{~nm}$.

trans-Dichlorobis[2,6-bis(zinc 10,15,20-triphenylporphyrin-5-yl)-3,5-

dimethylpyrazine] palladium(II) (4)

A solution of trans- $\mathrm{PdCl}_{2}\left(\mathrm{CH}_{3} \mathrm{CN}\right)_{2}$ in benzene $(1.7 \mathrm{mM}, 0.332 \mathrm{~mL})$ was added dropwise to a solution of $2(1.5 \mathrm{mg}, 1.1 \mu \mathrm{mol})$ in benzene $(3 \mathrm{~mL})$. After refluxing for $4 \mathrm{~h}$, the solution was evaporated in vacuo to afford a mixture of $4(50 \%)$ and starting material 2, which was identified by NMR spectroscopy. The very limited solubility of the product and partial dissociation of the complex in solution precluded further purification. ${ }^{1} \mathrm{H} \mathrm{NMR}\left(270 \mathrm{MHz}, \mathrm{C}_{6} \mathrm{D}_{5} \mathrm{CD}_{3}\right): \delta 4.33\left(\mathrm{~s}, 12 \mathrm{H}, \mathrm{Pz}-\mathrm{CH}_{3}\right), 7.42-7.61(\mathrm{~m}$, 36H, PhH), 8.03-8.28 (m, 24H, PhH), 8.85 (s, 8H, $\beta$-pyrrole), 8.86 (s, 8H, $\beta$-pyrrole), $9.11(\mathrm{~d}, J=4.9 \mathrm{~Hz}, 8 \mathrm{H}, \beta$-pyrrole), $9.56 \mathrm{ppm}(\mathrm{d}, J=4.6 \mathrm{~Hz}, 8 \mathrm{H}, \beta$-pyrrole).

\section{${ }^{1} \mathrm{H}$ NMR titration experiment of 1 with $C_{70}$ in toluene-d $d_{8}$ general procedure}

A solution of 1 in toluene- $d_{8}(600 \mu \mathrm{L}, 0.956 \mathrm{mM})$ was placed in an NMR sample tube and ${ }^{1} \mathrm{H}$ NMR spectra were recorded after each addition of 40, 80, 120 and $160 \mu \mathrm{L}$ of a solution of $\mathrm{C}_{70}$ in toluene- $d_{8}(1.52 \mathrm{mM})$. The association constant $K_{\mathrm{a}}$ was evaluated 
from the change $(\Delta \delta)$ in the chemical shifts of the $\beta$-pyrrole proton $a$ of $\mathbf{1}$ by applying a nonlinear curve-fitting method using the equation shown below:

$\Delta \delta=\Delta \delta_{\max }\left(\left[\mathrm{C}_{70}\right]_{\mathrm{t}}+[\mathbf{1}]_{\mathrm{t}}+1 / \mathrm{K}_{\mathrm{a}}-\left(\left(\left[\mathrm{C}_{70}\right]_{\mathrm{t}}+[\mathbf{1}]_{\mathrm{t}}+1 / \mathrm{K}_{\mathrm{a}}\right)^{2}-4\left[\mathrm{C}_{70}\right]_{\mathrm{t}}[\mathbf{1}]_{\mathrm{t}}\right)^{1 / 2}\right) /\left(2[\mathbf{1}]_{\mathrm{t}}\right)$

where $\left[\mathrm{C}_{70}\right]_{\mathrm{t}}$ and $[\mathbf{1}]_{\mathrm{t}}$ are total concentrations of $\mathrm{C}_{70}$ and $\mathbf{1}$, respectively, and $\Delta \delta_{\max }$ is

$\Delta \delta$ at $100 \%$ complexation.

\section{Acknowledgements}

This work was supported by a Grant-in-Aid for Scientific Research (No. 20550125) from the Ministry of Education, Culture, Sports, Science and Technology (MEXT) of Japan. We thank Professor Tsutomu Katsuki and Dr. Tatsuya Uchida of Kyushu University for their measurements of ESI-MS spectra.

\section{Supplementary material}

Supplementary material (fluorescence titration data, full ESI-MS spectrum and full ${ }^{1} \mathrm{H}$

NMR spectra) associated with this article can be found online.

\section{References}

(1) (a) Günes, S.; Neugebauer, H.; Sariciftci, N. S. Chem. Rev. 2007, 107, 13241338. (b) Gómez, R.; Seoane, C.; Segura, J. L. Chem. Soc. Rev. 2007, 36, 1305-1322. (c) Martín, N.; Sánchez, L.; Herranz, M. Á.; Illescas, B.; Guldi, D. M. Acc. Chem. Res. 2007, 40, 1015-1024. (d) Mateo-Alonso, A.; Guldi, D. M.; Paolucci, F.; Prato, M. Angew. Chem. Int. Ed. 2007, 46, 8120-8126. (e) D'Souza, F.; Ito, O. Coord. Chem. Rev. 2005, 249, 1410-1422.

(2) (a) Tashiro, K.; Aida, T. Chem. Soc. Rev. 2007, 36, 189-197. (b) Boyd, P. D.W.; Reed, C. A. Acc. Chem. Res. 2005, 38, 235-242. (c) Wu, Z.-Q.; Shao, X.-B.; Li, C.; Hou, J.-L.; Wang, K.; Jiang, X.-K.; Li, Z.-T. J. Am. Chem. Soc. 2005, 127, 17460-17468.

(3) (a) Imahori, H. J. Mater. Chem. 2007, 17, 31-41. (b) Kuramochi, Y.; Satake, A.; Itou, M.; Ogawa, K.; Araki, Y.; Ito, O.; Kobuke, Y. Chem. Eur. J. 2008, 14, 2827-2841. (c) Trabolsi, A.; Urbani, M.; Delgado, J. L.; Ajamaa, F.; 
Elhabiri, M.; Solladié, N.; Nierengarten, J.-F.; Albrecht-Gary, A.-M. New J. Chem. 2008, 32, 159-165. (d) Hasobe, T.; Saito, K.; Kamat, P. V.; Troiani, V.; Qiu, H.; Solladié, N.; Kim, K. S.; Park, J. K.; Kim, D.; D’Souza, F.; Fukuzumi, S. J. Mater. Chem. 2007, 17, 4160-4170. (e) Tong, L. H.; Wietor, J.-L.; Clegg, W.; Raithby, P. R.; Pascu, S. I.; Sanders, J. K. M. Chem. Eur. J. 2008, 14, 3035-3044. (f) Sygula, A.; Fronczek, F.R.; Sygula, R.; Rabideau, P. W.; Olmstead, M. M. J. Am. Chem. Soc. 2007, 129, 3842-3843. (g) Pérez, E. M.; Sierra, M.; Sánchez, L.; Torres, M. R.; Viruela, R.; Viruela, P. M.; Ortí, E.; Martín, N. Angew. Chem. Int. Ed. 2007, 46, 1847-1851. (h) Nielsen, K. A.; Martín-Gomis, L.; Sarova, G. H.; Sanguinet, L.; Gross, D. E.; FernándezLázaro, F.; Stein P. C.; Levillain, E.; Sessler, J. L.; Guldi, D. M.; SastreSantos, Á.; Jeppesen, J. O. Tetrahedron 2008, 64, 8449-8463. (i) Kawase, T.; Kurata, H. Chem. Rev. 2006, 106, 5250-5273. (j) Arimura, T.; Nishioka, T.; Suga, Y.; Murata, S.; Tachiya, M. Mol. Cryst. Liq. Cryst. 2002, 379, 413-418. (k) Scheer, M.; Sachindler, A.; Merkle, R.; Johnson, B. P.; Linseis, M.; Winter, R.; Anson, C. E.; Virovets, A. V. J. Am. Chem. Soc. 2007, 129, 13386-13387.

(4) Bhattacharya, S.; Shimawaki, T.; Peng, X.; Ashokkumar, A.; Aonuma, S.; Kimura, T.; Komatsu, N. Chem. Phys. Lett. 2006, 430, 435-442.

(5) Dudič, M.; Lhoták, P.; Stibor, I.; Petrríčková, H.; Lang, K. New J. Chem. 2004, 28, 85-90.

(6) Hosseini, A.; Taylor, S.; Accorsi, G.; Armaroli, N.; Reed, C. A.; Boyd, P. D. W. J. Am. Chem. Soc. 2006, 128, 15903-15913.

(7) Kubo, Y.; Sugasaki, A.; Ikeda, M.; Sugiyasu, K.; Sonoda, K.; Ikeda, A.; Takeuchi, M.; Shinkai, S. Org. Lett. 2002, 4, 925-928.

(8) Eda, Y.; Itoh, K.; Ito, Y. N.; Kawato, T. Tetrahedron 2009, 65, 282-288.

(9) (a) Mutou, T.; Amimoto, K.; Kanatomi, H.; Koyama, H.; Kawato, T. Chem. Lett. 1999, 1231-1232. (b) Kawato, T.; Koyama, H.; Kanatomi, H.; Muramoto, Y. Inorg. Chim. Acta 1991, 183, 107-112.

(10) Sun, D.; Tham, F. S.; Reed, C. A.; Chaker, L.; Burgess, M.; Boyd, P. D. W. J. Am. Chem. Soc. 2000, 122, 10704-10705.

(11) (a) Stubbe, J.; Nocera, D. G.; Yee, C. S.; Chang, M. C. Y. Chem. Rev. 2003, 103, 2167-2202. (b) Pullerits, T.; Sundström, V. Acc. Chem. Res. 1996, 29, 381-389. 